\title{
Mechanical properties of cassava starch films as affected by different plasticizers and different relative humidity conditions
}

\author{
Jeannine Bonilla Lagos ${ }^{\mathrm{a}}$, Nívea M. Vicentini ${ }^{\mathrm{b}}$, Rodolfo M.C. Dos Santos ${ }^{\mathrm{a}}$, Ana \\ MÔnica Q.B. BitTante ${ }^{a}$, And Paulo J.A. Sobrat ${ }^{a^{*}}$

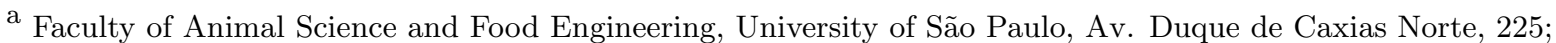 \\ 13635-900 Pirassununga (SP) Brazil \\ b Embrapa Gado de Leite, R. Eugênio do Nascimento, 610. 36038-330 Juiz de Fora (MG) Brazil \\ ${ }^{*}$ Corresponding author \\ pjsobral@usp.br
}

Received: 11 December 2014; Published online: 18 April 2015

\begin{abstract}
The influence of plasticizer type (glycerol and sorbitol), its content (starch:plasticizer ratio of 1:0.15; 1:0.20; 1:0.25 and 1:0.30) and the relative humidity conditions (43, 58, 75 and 85\%) on the mechanical properties of cassava starch films was studied. Both plasticizers seemed to integrate homogeneously in the film matrix. The incorporation of different concentrations of plasticizers affected the mechanical properties of the cassava starch films. Plasticizer ratio directly influenced the force values of the films, they showed significant flexibility when the plasticizer proportion was increased in the formulation. Under conditions of low relative humidity, sorbitol produced films more resistant to puncture than glycerol. Qualitatively, all the films were less brittle when the plasticizers were incorporated.
\end{abstract}

Keywords: Edible films; Mechanical essays; Puncture tests; Glycerol; Sorbitol; Models

\section{Introduction}

Many studies about the development and/or applications of edible and/or biodegradable materials from biopolymers, products and by-products of agro materials and renewable sources, have been studied recently. Specifically, there is great interest in edible films or coatings, which imply the use of materials and food grade additives in their formulations. The main component of these materials is a biopolymer, which must be able to form a continuous matrix. The coating is produced directly on the product to be covered, whereas the edible film is produced on a support, to be taken off later. Thus, this material, which is a thin and flexible film, can be used to manufacture food packaging.

According to Bonilla, Atares, Vargas, and Chiralt (2013), biodegradable polymers based on natural polysaccharides, particularly starch, can be produced at low cost and on a large scale and their applications in food packaging are promising due to their environmental appeal, flexibility, transparency, thermoplastic properties and low cost. Starches from different sources like cassava, potatoes, corn, wheat and rice, natural or modified, have been used in the preparation of coatings (García, Martino, \& Zaritzky, 1998) and edible films (Stading, Rindlav-Westling, \& Gatenholm, 2001; Forssell, Partanen, Buleon, Farhat, \& Myllarinen, 2002; Mali \& Grossmann, 2003; Ollett, Parker, \& Smith, 1991; Lourdin, DellaValle, \& Colonna, 1995).

In particular, cassava starch (Manihot esculenta $C$.) is an important source in some countries like Brazil, which is the largest cassava producing country, as well as in Thailand, Malaysia, In- 
donesia and some regions of Africa (Zhu, 2014; Versino \& Alejandra Garcia, 2014). This starch is a cheap and abundant material, able to form a continuous polymer matrix (Bergo, Freitas Moraes, \& do Amaral Sobral, 2012; Bergo, Sobral, \& Prison, 2010; Bergo, Sobral, Guevara, \& Vadala, 2010; Bergo et al., 2008), even without plasticizer (Vicentini, Dupuy, Leitzelman, Cereda, \& Sobral, 2005). It has attracted particular interest because it is able to form edible films and coatings (Vicentini \& Cereda, 1999; Vicentini, Castro, \& Cereda, 1999; Henrique \& Cereda, 1999; Oliveira \& Cereda, 1999) and flexible, tasteless, odourless, colourless, transparent, nontoxic and biologically degradable films (Chiumarelli \& Hubinger, 2014; Belibi et al., 2014; Chang, Cheah, \& Seow, 2000).

However, cassava starch films produced without plasticizers exhibit poor mechanical strength and become fragile with low water content (Vicentini et al., 2005). An alternative to avoid such brittle characteristic would be the use of plasticizers, such as some low molecular polyols (Liu, Xie, Yu, Chen, \& Li, 2009; Mali, Sakanaka, Yamashita, \& Grossmann, 2005; Ramírez et al., 2011; Gontard, Guilbert, \& Cuq, 1993; Cuq, Gontard, Cuq, \& Guilbert, 1997). Usually, increasing the concentration of plasticizer leads to reduction of mechanical resistance and rigidity and increasing deformability of films, but the behavior depends on the type of plasticizer used (Sobral, Menegalli, Hubinger, \& Roques, 2001; Gontard et al., 1993; Gennadios, Park, \& Weller, 1993; Cuq, Gontard, Cuq, \& Guilbert, 1997; Debeaufort \& Voilley, 1997). The concentration of plasticizers generally ranges from 10 to $60 \mathrm{~g} / 100 \mathrm{~g}$ dry matter, depending on the rigidity of the polymer (Lazaridou \& Biliaderis, 2002), while moisture content of the film is dependent on the relative humidity of the environment in which it is stored (Chang et al., 2000; Gennadios et al., 1993).

In this context, the aim of this work was to analyze the effect of glycerol and/or sorbitol incorporation on the mechanical properties of cassava starch films at different relative humidities.

\section{Materials and Methods}

\subsection{Preparation of the films}

Cassava starch (Manihot esculenta $C$.) was supplied by Flor de Lótus (São Paulo, Brazil), previously characterized by Vicentini, Sobral, and Cereda (2002). The plasticizers studied were glycerol $\left(\mathrm{C}_{3} \mathrm{H}_{8} \mathrm{O}_{3}, \mathrm{MW}=92 \mathrm{~g} / \mathrm{gmol}\right)$ and sorbitol $\left(\mathrm{C}_{6} \mathrm{H}_{14} \mathrm{O}_{6}, \mathrm{MW}=182 \mathrm{~g} / \mathrm{gmol}\right)$ provided by Nuclear U.S.P, Brazil.

The film-forming solutions (FFS) were prepared with $2 \mathrm{~g}$ starch $/ 100 \mathrm{~g}$ of water weighed in a semianalytical balance $( \pm 0.01 \mathrm{~g})$ (Mars, AS2000). The FFS were heated at $70^{\circ} \mathrm{C}$ in a water bath (Tecnal, TE 184) for $40 \mathrm{~min}$ with constant mechanical stirring (Tecnal TE 039) to promote starch gelatinization. Plasticizer was afterwards added to the starch solution in starch:plasticizer ratios of $1: 0.15 ; 1: 0.20 ; 1: 0.25$ and 1:0.30. The FFSs $(60 \mathrm{~g})$ were cast in petri dishes polycarbonate $\left(139.2 \mathrm{~cm}^{2}\right)$ and dried in an oven (Tecnal, MA037-3) with the temperature $\left(30^{\circ} \mathrm{C} \pm\right.$ $0.5)$ and relative humidity $(55-65 \%)$ controlled. These techniques have been used in previously works (Bergo, Sobral, \& Prison, 2010; Bergo et al., 2008).

Prior to characterization, the films were conditioned for 6 days at $25^{\circ} \mathrm{C}$ in desiccators containing saturated solutions of $\mathrm{K}_{2} \mathrm{CO}_{3}, \mathrm{NaBr}, \mathrm{NaCl}$, $\mathrm{KCl}$ which provided environments with a relative humidity $(\mathrm{RH})$ of $43,58,75$ and $85 \%$, respectively (Bergo et al., 2012).

\subsection{Thickness of the films}

The film thickness was measured using a digital micrometer (Mitutyo, Japan) to the nearest $0.001 \mathrm{~mm}$. Nine random positions in each film samples were measured.

\subsection{Moisture of the films}

Once equilibrated, film samples were taken from each formulation to determine the moisture content by means of a gravimetric method. Firstly, $1 \mathrm{~g}$ of film was weighed using an analytical balance (Scientech SA-210) to the nearest 0.0001g. The samples were dried in an oven at $105^{\circ} \mathrm{C}$ for 
$24 \mathrm{~h}$ until constant weight, as described by (Bergo et al., 2012). The moisture content (MC) was expressed as the $\mathrm{g}$ of water $/ 100 \mathrm{~g}$ of the dried film. The results from at least four samples were averaged.

\subsection{Mechanical properties}

Mechanical properties of the films were determined by puncture tests, using a Universal Testing Machine (TA.XT2i Stable Micro System) at room temperature $\left(25^{\circ} \mathrm{C}\right)$. Four replicates were carried out for each formulation and test.

The puncture force $(\mathrm{PF})$ and deformation $(\mathrm{PD})$ were determined according to the methodology established in the literature (Cuq, Gontard, \& Guilbert, 1997; Gontard \& Ring, 1996). The films were fixed in cells with $52.6 \mathrm{~mm}$ diameter aperture and perforated by a probe of $3 \mathrm{~mm}$ diameter, moving at $1 \mathrm{~mm} / \mathrm{s}$. The puncture force $(\mathrm{PF}, \mathrm{N})$ and displacement were obtained directly from the force curves as a function of probe displacement. Then, puncture deformation (PD, \%) was calculated from the distance travelled by the probe to the puncture displacement.

\subsection{Statistical analysis}

The statistical analysis of the data was performed by analysis of variance (ANOVA) using Statgraphics Plus (Manugistics Corp., Rockville, MD). Fisher's least significant difference (LSD) procedure was used to compare the means. Mechanical values were fitted to multiple regression equations using the design factors (concentration of each plasticizer and relative humidities) as independent variables, using the Statgraphics program.

\section{Results and Discussion}

\subsection{Thickness of cassava starch films}

The results of the thickness of the films conditioned at $25^{\circ} \mathrm{C}$ and four different relative humidities $(43,58,75,85 \%)$, with the incorporation of two different plasticizers (glycerol and sorbitol) are shown in Table 1.

Although all films were cast at a constant mass/surface ratio (60 $\mathrm{g}$ solids $/ \mathrm{cm}^{2}$ ), the final thickness of the films conditioned at the same relative humidity differed significantly $(\mathrm{p}<0.05)$ as a function of the starch/plasticizer. The film thickness tended to increase when the starch ratio decreased in the film. The behavior regarding the plasticizer was explained by the fact that when the solution was more concentrated in plasticizer, a larger amount of dry matter (starch + plasticizer) was added, thereby resulting in increased thickness of the films, as described other authors (Sobral, 2000; Vicentini et al., 2002). The greater changes in the thickness in films with glycerol incorporated were presented in the films conditioned at $75 \% \mathrm{HR}$ (from $0.064 \pm 0.005$ to $0.084 \pm 0.006)$. In the case of the films with sorbitol added, the greatest changes in the thickness were at $58 \% \mathrm{HR}$ (from $0.059 \pm 0.005$ to 0.081 $\pm 0.005)$.

Moreover, the thickness of the films with glycerol incorporated at different $\mathrm{RH}$ did not differ significantly $(\mathrm{p}>0.05)$. However, the films with sorbitol were significantly different $(\mathrm{p}<0.05)$. These results were possibly due to sorbitol have more hydroxyl groups to interact with water by hydrogen bonds than glycerol.

\subsection{Moisture of cassava starch films}

The conditioning of the samples at different relative humidities caused water vapour adsorption of the films increasing its moisture content, as shown in Fig. 1. According to da Matta, Sarmento, Sarantopoulos, and Zocchi (2011), the plasticizer addition, in particular glycerol, has a great influence on starch films moisture, due to its hygroscopic character. Moreover, glycerol interacts with the film matrix by increasing the space between the chains, facilitates water migration into the film and, consequently, increases solubility.

In general in this study, the incorporation of glycerol made the films slightly more hygroscopic than when sorbitol was added. Molecular differences between glycerol and sorbitol were probably responsible for the different sorption be- 
Mechanical properties of cassava starch films $\mid 119$

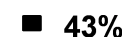

ㅁ $\mathbf{5 8 \%}$

ㅁ $\mathbf{7 5} \%$

- $85 \%$

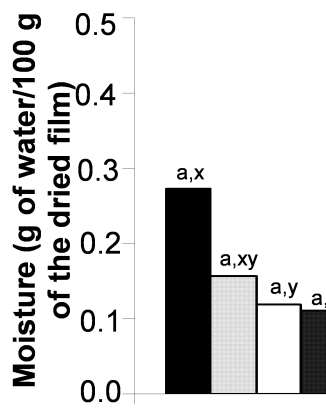

15

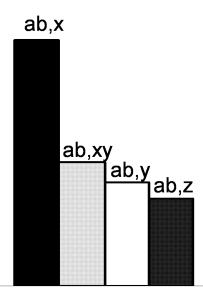

20

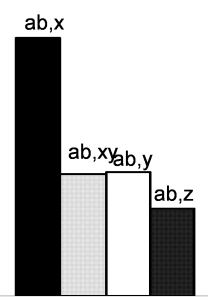

25

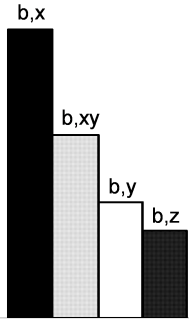

30

Glycerol concentration (g/100g of starch)
- $43 \%$
$\square \quad 58 \%$
$\square \mathbf{7 5 \%}$
- $85 \%$

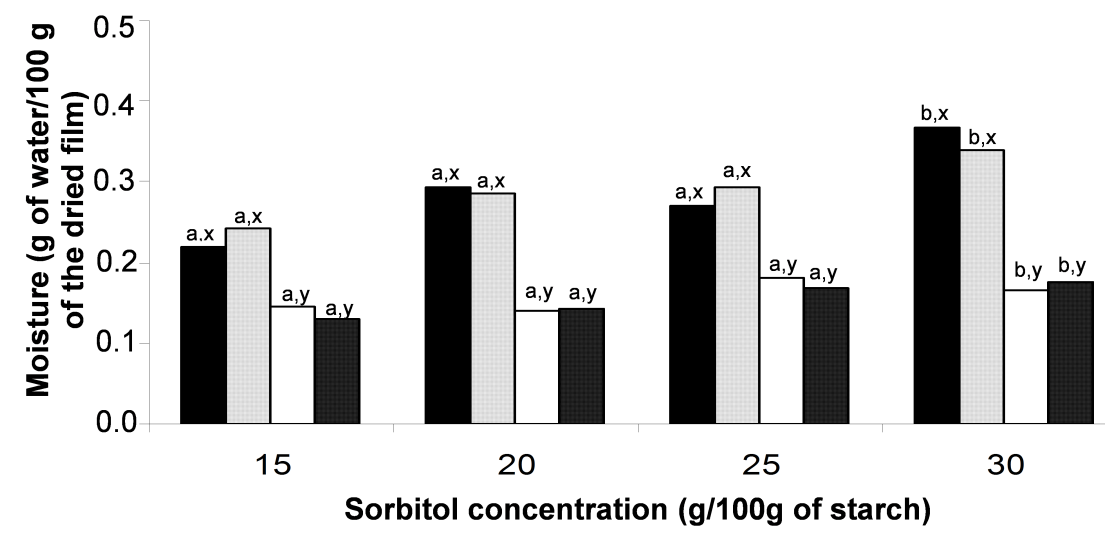

Figure 1: Moisture content of cassava starch films plasticized with glycerol and sorbitol. Values of concentration of plasticizer with the superscripts ( $\mathrm{a}, \mathrm{b}$ or, $\mathrm{c}$ ) and relative humidity ( $\mathrm{x}, \mathrm{y}$ or $\mathrm{x}$ ) were not significantly different in the LSD test 
$120 \mid$ Lagos et al.

Table 1: Thickness ${ }^{1}(\mathrm{~mm})$ of cassava starch films with different plasticizers and conditioned in different relative humidities ${ }^{2}$

\begin{tabular}{ccccc}
\hline \multirow{2}{*}{$\begin{array}{c}\text { Plasticizer } \\
\text { concentration }\end{array}$} & \multicolumn{5}{c}{ Relative humidity of conditioning } \\
\cline { 2 - 6 } & \multicolumn{5}{c}{$5 \% \%$} & $75 \%$ & $85 \%$ \\
\hline Glycerol & $0.069(0.006)^{a . x}$ & $0.070(0.004)^{a . x}$ & $0.064(0.005)^{a . x}$ & $0.064(0.005)^{a . x}$ \\
15 & $0.067(0.007)^{a b . x}$ & $0.070(0.004)^{a b . x}$ & $0.082(0.036)^{a b . x}$ & $0.082(0.036)^{a b . x}$ \\
20 & $0.070(0.004)^{a b . x}$ & $0.065(0.005)^{a b . x}$ & $0.074(0.005)^{a b . x}$ & $0.082(0.005)^{a b . x}$ \\
25 & $0.071(0.004)^{b . x}$ & $0.086(0.006)^{b . x}$ & $0.084(0.006)^{b . x}$ & $0.079(0.004)^{b . x}$ \\
30 & & & & \\
Sorbitol & $0.073(0.005)^{a . x y}$ & $0.059(0.005)^{a . x}$ & $0.067(0.004)^{a . x y}$ & $0.081(0.004)^{a . y}$ \\
15 & $0.079(0.007)^{a b . x y}$ & $0.070(0.004)^{a b . x}$ & $0.070(0.004)^{a b . x y}$ & $0.081(0.004)^{a b . y}$ \\
20 & $0.073(0.006)^{a b . x y}$ & $0.074(0.005)^{a b . x}$ & $0.087(0.006)^{a b . x y}$ & $0.079(0.004)^{a b . y}$ \\
25 & $0.076(0.005)^{b . x y}$ & $0.081(0.005)^{b . x}$ & $0.086(0.007)^{b . x y}$ & $0.085(0.006)^{b . y}$ \\
30 &
\end{tabular}

${ }^{1}$ Mean values (standard deviation).

${ }^{2}$ Values of concentration of plasticizer (columns) with the same superscript (a, b or c) and relative humidity (rows) with the same superscript ( $\mathrm{x}, \mathrm{y}$ or $\mathrm{z}$ ) were not significantly different in the LSD test

haviour of films plasticized by them. Glycerol and sorbitol are polyols with similar straightchain molecules; however, the glycerol molecule is smaller ( $\mathrm{MW}=92 \mathrm{~g} / \mathrm{gmol}$ ) and has three hydroxyl groups, while the sorbitol molecule (MW $=182 \mathrm{~g} / \mathrm{gmol}$ ) has six hydroxyl groups. Although sorbitol presented more hydroxyl groups to interact with water by hydrogen bonds, glycerol presented higher water affinity demonstrated by adsorption and desorption isotherms. Since sorbitol is more similar to the molecular structure of glucose than glycerol, the chances of sorbitol interacting with polymeric starch chains are higher, thus, sorbitol containing films presented higher intermolecular forces and showed a lower capacity to interact with water (Mali et al., 2005). Similar results were reported by Mali et al. (2005) and Alves, Mali, Beleia, and Grossmann (2007), who also studied the influence of the plasticizer in cassava starch films.

\subsection{Mechanical properties of cassava starch films}

A food packaging generally requires high stress with deformation according to the intended application. In general, a food packaging must be an undeformable material to provide structural integrity or reinforce food structure, or even, a deformable film for other applications (Alves et al., 2007).

The results of puncture test are shown in Fig. 2. In general, it was observed that the films became more extendible when the concentration of plasticizer and relative humidity conditioning were increased. The reduction of the puncture force and the increasing of puncture deformation were consequences of the incorporation of plasticizers, and to water molecules absorbed by the samples, a common phenomenon of edible films, as has been revealed in other studies (Sobral et al., 2001; Cuq, Gontard, Cuq, \& Guilbert, 1997; Debeaufort \& Voilley, 1997; Ollett et al., 1991; Gennadios et al., 1993; Gontard et al., 1993). The significant increase in hydration of the films, produced by increase in relative humidity, caused a swelling of the biopolymer matrix, thus leading to an increase in the mobility of polymer chains. This made the bond strengths between them weaker, which consequently contributed to the decrease in strength and rigidity of the films (Chang et al., 2000; Cuq, Gontard, Cuq, \& Guilbert, 1997; Gontard et al., 1993).

Comparing both plasticizers, it was observed that, in general, and especially at lower relative humidity, the films were more resistant to puncture obtained by using sorbitol, with the force 

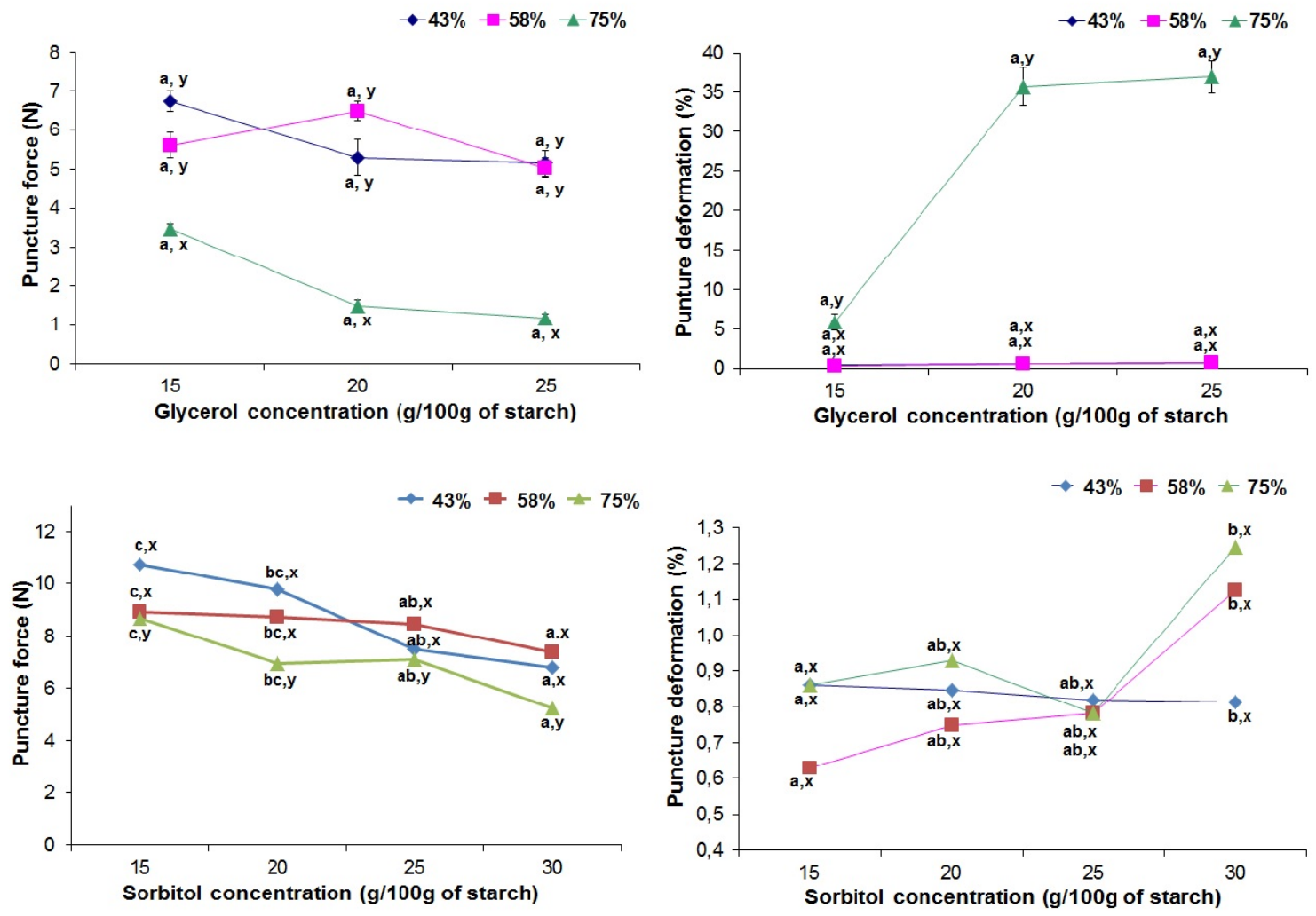

Figure 2: Mechanical properties of cassava starch films plasticized with glycerol and sorbitol. Values for concentration of plasticizer with the same superscript $(\mathrm{a}, \mathrm{b}$ or $\mathrm{c}$ ) and the relative humidity $(\mathrm{x}, \mathrm{y}$ or $\mathrm{z})$ were not significantly different in the LSD test

values at the puncture between 3 and $12 \mathrm{~N}$, while the least resistant were those made with glycerol, with values between 1 and $8 \mathrm{~N}$. This behaviour was consequence of the higher plasticizer effect of glycerol.

All films conditioned at lower relative humidity showed very small puncture deformation, practically independently of the concentration of plasticizer. In conditions of high relative humidity $(75 \%)$, the films with glycerol showed higher puncture deformation values (variation between 15 and $30 \mathrm{~g}$ plasticizer $/ 100 \mathrm{~g}$ starch), resulting in more deformable films, with values ranging from 1 and $32 \%$. The opposite results were obtained with sorbitol. This behaviour could be explained by the increase of the molecular weight from glycerol to sorbitol. Lourdin et al. (1995) observed that the addition of glycerol as plasticizer above $20 \%$ changes the mechanical behaviour of starch films by extending the plasticity zone.

Chen and Lai (2008) studied the puncture characteristics of tapioca starch/decolorized hsiantsao (dHG) leaf gum films in the presence of glycerol. As glycerol concentration increased from $25 \%$ to $40 \%$, the greater incorporation of glycerol into starch/dHG network resulted in reduction of puncture strength and an increase of puncture deformation. However, the formation of junction zones between starch and dHG still yielded films having higher puncture strength and lower puncture deformation than films without dHG.

According to Maran, Sivakumar, Sridhar, and Immanuel (2013), the puncture deformation was increased due to the increase in mobility of poly- 
$122 \mid$ Lagos et al.

Table 2: Coefficients and significance of regression models to mechanical properties according to the concentration of plasticizers, moisture and thickness conditions for obtaining cassava starch films

\begin{tabular}{clcc}
\hline \multirow{2}{*}{ Plasticizers } & \multicolumn{1}{c}{ Term } & $\begin{array}{c}\text { Puncture force } \\
(\mathbf{P F}, \mathbf{N})\end{array}$ & $\begin{array}{c}\text { Puncture deformation } \\
(\mathbf{P D}, \mathbf{\%})\end{array}$ \\
\hline \multirow{2}{*}{ Glycerol } & Model & $0.0109^{*}$ & $0.0160^{*}$ \\
& Constant & $0.0047^{*}$ & $0.0083^{*}$ \\
& Concentration of plasticizers & 0.1046 & 0.2500 \\
& (g/100g of starch) & $0.0078^{*}$ & $0.0353^{*}$ \\
& Moisture (\%) & 0.1325 & $0.0277^{*}$ \\
& Thickness (mm) & 92.2585 & 90.616 \\
\hline \multirow{2}{*}{ Sorbitol } & $\mathrm{R}^{2}(\%)$ & $0.0024^{*}$ & 0.8366 \\
& Model & $0.0006^{*}$ & 0.3256 \\
& Constant & $0.0014^{*}$ & 0.6931 \\
& Concentration of plasticizers & $0.0030^{*}$ & 0.8201 \\
& (g/100g of starch) & $0.0168^{*}$ & 0.4390 \\
& Moisture (\%) & 96.4299 & 17.47 \\
\hline
\end{tabular}

* Level of significance $(95.0 \%)$

mer chains in the presence of glycerol in the tapioca starch films. The permeated glycerol molecules could further decrease the interactions among the starch macromolecules, because of the formation of hydrogen bonds between the hydroxyl groups of starch macromolecules and glycerol small molecules. These all are favourable to the movement and rearrangement of the macromolecule chains of the starch, which caused the increase in the flexibility of the starch films. On other hand, puncture force was enhanced with increasing starch content. Sobral et al. (2001) observed that puncture deformation values of gelatin film increases with increasing plasticizer content. In that study, puncture force and deformation varied between 5.6-13.2 $\mathrm{N}$ and 3.5-4.7 $\mathrm{mm}$ respectively.

Table 2 shows the results of adjusting a multiple linear regression model to describe the relationship between mechanical properties (puncture force and puncture deformation) and three independent variables (concentration of plasticizers, thickness and moisture content). The equations of the fitted models applied on puncture force, using glycerol (Eq. 1) or sorbitol (Eq. 2) are presented. The R-square $\left(\mathrm{R}^{2}\right), 92.3 \%$ and $96.4 \%$ to the incorporation of glycerol and sorbitol respectively, indicated variability of the re- sults with respect to this property.

$$
\begin{aligned}
& P F=19.9-0.13 \cdot C g-101.2 \cdot X-0.10 \cdot M \\
& P F=12.1-0.33 \cdot C s+83.2 \cdot X-0.05 \cdot M
\end{aligned}
$$

where $C g$ and $C s$ are concentrations (g/100g of starch) of glycerol and sorbitol, respectively; $X$ is the thickness (mm) and $M$ is the moisture content (\%).

On other hand, only the equation of the model fitted to puncture deformation of data of films with glycerol was significant $(5 \%)$ (Eq. 3). The $\mathrm{R}$-square $\left(\mathrm{R}^{2}\right), 90.6 \%$ indicated the variability of the results with respect to this property.

$$
P D=-151.1+0.73 \cdot C g+1613.1 \cdot X+0.57 \cdot M
$$

\section{Conclusions}

The incorporation of different concentrations of plasticizers affected the mechanical properties of the cassava starch films. Glycerol and sorbitol plasticizer addition made films more flexible and homogeneous. Under conditions of low relative humidity, sorbitol produced films more resistant to puncture than glycerol. In conditions of high relative humidity and higher concentration of 
plasticizer, particularly glycerol, the films were more deformable at break and were slightly more hygroscopic. The increasing of relative humidity of conditioning and of the plasticizers concentration resulted in an increase of thickness of the films, principally in the case of the films with sorbitol incorporated.

\section{Acknowledgements}

To the São Paulo Research Foundation (FAPESP) for the financial support (01/03577$0)$, Postdoctoral fellowship of Jeannine Bonilla Lagos (14/03288-8), Doctoral fellowship of Nívea M. Vicentini (98/16179-8) and Scientific Initiation fellowship of Rodolfo M.C. dos Santos (02/09829-3), and to Brazilian National Council for Scientific and Technological Development (CNPq) for the Research fellowship of Paulo J.A. Sobral.

\section{References}

Alves, V. D., Mali, S., Beleia, A., \& Grossmann, M. V. E. (2007). Effect of glycerol and amylose enrichment on cassava starch film properties. Journal of Food Engineering, 78(3), 941-946. doi:10.1016/j.jfoodeng. 2005.12.007

Belibi, P. C., Daou, T. J., Ndjaka, J. M. B., Nsom, B., Michelin, L., \& Durand, B. (2014). A comparative study of some properties of cassava and tree cassava starch films. Physics Procedia, 55, 220-226. doi:10.1016/j.phpro.2014.07.032

Bergo, P. V. A., Carvalho, R. A., Sobral, P. J. A., dos Santos, R. M. C., da Silva, F. B. R., Prison, J. M., ... Habitante, A. M. Q. B. (2008). Physical properties of edible films based on cassava starch as affected by the plasticizer concentration. Packaging Technology and Science, 21(2), 85-89. doi:10. $1002 /$ pts.781

Bergo, P., Sobral, P. J. A., Guevara, V. C. I., \& Vadala, A. C. S. (2010). Semi crystalline behaviour of cassava starch films plasticized with glycerol. In L. Rosa \& F. Margarido (Eds.), Advanced materials forum $v$, pt 1 and 2 (Vol. 636-637, 1-2, pp. 745-752). Materials Science Forum. 5th International Materials Symposium/14th Conference of the Sociedade-Portuguesade-Materiais, Lisbon, Portugal, Apr 05-08, 2009. doi:10 . 4028 / www . scientific . net / MSF.636-637.745

Bergo, P., Sobral, P. J. A., \& Prison, J. M. (2010). Effect of glycerol on physical properties of cassava starch films. Journal of Food Processing and Preservation, 34(2), 401-410. doi:10.1111/j. 1745-4549.2008. 00282.x

Bergo, P., Freitas Moraes, I. C., \& do Amaral Sobral, P. J. (2012). Effects of moisture content on structural and dielectric properties of cassava starch films. Starchstarke, 64(10), 835-839. doi:10.1002/star. 201200023

Bonilla, J., Atares, L., Vargas, M., \& Chiralt, A. (2013). Properties of wheat starch filmforming dispersions and films as affected by chitosan addition. Journal of Food Engineering, 114(3), 303-312. doi:10.1016/j. jfoodeng.2012.08.005

Chang, Y. P., Cheah, P. B., \& Seow, C. C. (2000). Plasticizing-antiplasticizing effects of water on physical properties of tapioca starch films in the glassy state. Journal of Food Science, 65(3), 445-451. doi:10.1111/j . 1365-2621.2000.tb16025.x

Chen, C.-H. \& Lai, L.-S. (2008). Mechanical and water vapor barrier properties of tapioca starch/decolorized hsian-tsao leaf gum films in the presence of plasticizer. Food Hydrocolloids, 22(8), 1584-1595. doi:10 . 1016/j.foodhyd.2007.11.006

Chiumarelli, M. \& Hubinger, M. D. (2014). Evaluation of edible films and coatings formulated with cassava starch, glycerol, carnauba wax and stearic acid. Food Hydrocolloids, 38, 20-27. doi:10.1016/j.foodhyd. 2013.11.013

Cuq, B., Gontard, N., Cuq, J. L., \& Guilbert, S. (1997). Selected functional properties of fish myofibrillar protein-based films as affected by hydrophilic plasticizers. Journal of Agricultural and Food Chemistry, 45(3), 622-626. doi:10.1021/jf960352i

Cuq, B., Gontard, N., \& Guilbert, S. (1997). Thermal properties of fish myofibrillar 
protein-based films as affected by moisture content. Polymer, 38(10), 2399-2405. doi:10.1016/S0032-3861(96)00781-1

da Matta, M. D., Jr., Sarmento, S. B. S., Sarantopoulos, C. I. G. L., \& Zocchi, S. S. (2011). Barrier properties of films of pea starch associated with xanthan gum and glycerol. Polimeros-Ciencia e Tecnologia, 21(1), 67 72. doi:10.1590/S0104-14282011005000011

Debeaufort, F. \& Voilley, A. (1997). Methylcellulose-based edible films and coatings .1. mechanical and thermal properties as a function of plasticizer content. Journal of Agricultural and Food Chemistry, 45(3), 685-689. doi:10.1021/jf9606621

Forssell, P., Partanen, R., Buleon, A., Farhat, I., \& Myllarinen, P. (2002). Behaviour of amylose and amylopectin films. In D. Renard, G. D. Valle, \& Y. Popineau (Eds.), Plant biopolymer science: food and nonfood applications (pp. 235-240). Workshop on Plant Biopolymer Science, NANTES, FRANCE, JUN 25-27, 2001. doi:10.1039/ 9781847551672-00235

García, M. A., Martino, M. N., \& Zaritzky, N. E. (1998). Plasticized starch-based coatings to improve strawberry (fragaria x ananassa) quality and stability. Journal of Agricultural and Food Chemistry, 46(9), 37583767. doi:10.1021/jf980014c

Gennadios, A., Park, H. J., \& Weller, C. L. (1993). Relative-humidity and temperature effects on tensile-strength of edible protein and cellulose ether films. Transactions of the Asae, 36(6), 1867-1872.

Gontard, N., Guilbert, S., \& Cuq, J. L. (1993). Water and glycerol as plasticizers affect mechanical and water-vapor barrier properties of an edible wheat gluten film. Journal of Food Science, 58(1), 206-211. doi:10. 1111/j.1365-2621.1993.tb03246.x

Gontard, N. \& Ring, S. (1996). Edible wheat gluten film: influence of water content on glass transition temperature. Journal of Agricultural and Food Chemistry, 44(11), 3474-3478. doi:10.1021/jf960230q

Henrique, C. M. \& Cereda, M. P. (1999). Utilization of biofilms in the postharvest conservation of strawberry (fragaria ananassa duch) cv iac campinas. Food Science and Technology (Campinas), 19(2), 231-233.

Lazaridou, A. \& Biliaderis, C. (2002). Thermophysical properties of chitosan, chitosanstarch and chitosan-pullulan films near the glass transition. Carbohydrate Polymers, 48(2), 179-190. doi:10.1016/S01448617(01)00261-2

Liu, H., Xie, F., Yu, L., Chen, L., \& Li, L. (2009). Thermal processing of starch-based polymers. Progress in Polymer Science, 34 (12), 1348-1368. doi:10 . $1016 / \mathrm{j}$. progpolymsci . 2009.07.001

Lourdin, D., DellaValle, G., \& Colonna, P. (1995). Influence of amylose content on starch films and foams. Carbohydrate Polymers, 27(4), 261-270. doi:10.1016/01448617(95)00071-2

Mali, S. \& Grossmann, M. V. E. (2003). Effects of yam starch films on storability and quality of fresh strawberries (fragaria ananassa). Journal of Agricultural and Food Chemistry, 51(24), 7005-7011. doi:10 . 1021/ jf034241c

Mali, S., Sakanaka, L. S., Yamashita, F., \& Grossmann, M. V. E. (2005). Water sorption and mechanical properties of cassava starch films and their relation to plasticizing effect. Carbohydrate Polymers, 60(3), 283-289. doi:10.1016/j.carbpol.2005.01.003

Maran, J. P., Sivakumar, V., Sridhar, R., \& Immanuel, V. P. (2013). Development of model for mechanical properties of tapioca starch based edible films. Industrial Crops and Products, 42, 159-168. doi:10.1016/j. indcrop.2012.05.011

Oliveira, M. A. d. \& Cereda, M. P. (1999). Efeito da película de mandioca na conservaçao de goiabas $=$ the effet of cassava based film on the guavas. Brazilian Journal of Food Technology (Brasil), 2(1-2), 97-102. Retrieved from http://bjft.ital.sp.gov.br / artigos / html/busca/PDF/v02nu14a.pdf

Ollett, A. l., Parker, R., \& Smith, A. C. (1991). Deformation and fracture-behavior of wheat-starch plasticized with glucose and water. Journal of Materials Science, 26(5), 1351-1356. doi:10 . 1007 / BF00544476 
Ramírez, M. G. L., Satyanarayana, K. G., Iwakiri, S., de Muniz, G. B., Tanobe, V., \& Flores-Sahagun, T. S. (2011). Study of the properties of biocomposites. part i. cassava starch-green coir fibers from brazil. Carbohydrate Polymers, 86(4), 1712-1722.

Sobral, P. J. A. (2000). Influência da espessura de biofilmes feitos à base de proteínas miofibrilares sobre suas propriedades funcionais. Pesquisa Agropecuária Brasileira, $35(6), 1251-1259$.

Sobral, P. J. A., Menegalli, F. C., Hubinger, M. D., \& Roques, M. A. (2001). Mechanical, water vapor barrier and thermal properties of gelatin based edible films. Food Hydrocolloids, 15(4-6), 423-432. doi:10 . 1016/S0268-005X(01)00061-3

Stading, M., Rindlav-Westling, A., \& Gatenholm, P. (2001). Humidity-induced structural transitions in amylose and amylopectin films. Carbohydrate Polymers, 45(3), 209-217. doi:10 . 1016 / S0144 8617(00)00242-3

Versino, F. \& Alejandra Garcia, M. (2014). Cassava (manihot esculenta) starch films reinforced with natural fibrous filler. Industrial Crops and Products, 58, 305-314. doi:10. 1016/j.indcrop.2014.04.040

Vicentini, N. M., Castro, T.-s. M. R. D., \& Cereda, M. P. (1999, January). Influência de películas de fécula de mandioca na qualidade pós-colheita de frutos de pimentão (Capsicum annuum L.) Food Science and Technology (Campinas), 19, 127-130. doi:10 . 1590 / S0101 20611999000100023

Vicentini, N. M. \& Cereda, M. P. (1999). Uso de filmes de fécula de mandioca em póscolheita de pepino (cucumis sativus 1.) Brazilian Journal of Food Technology, 2(12), 87-90.

Vicentini, N. M., Dupuy, N., Leitzelman, M., Cereda, M. P., \& Sobral, P. J. A. (2005). Prediction of cassava starch edible film properties by chemometric analysis of infrared spectra. Spectroscopy Letters, 38(6), 749-767. doi:10.1080/00387010500316080

Vicentini, N. M., Sobral, P. J. D., \& Cereda, M. P. (2002). The influence of the thickness on the functional properties of cas- sava starch edible films. In D. Renard, G. Valle, \& Y. Popineau (Eds.), Plant biopolymer science: food and non-food applications (pp. 291-300). Workshop on Plant Biopolymer Science, Nantes, France, Jun 25-27, 2001. doi:10.1039/9781847551672-00291

Zhu, F. (2014). Composition, structure, physicochemical properties, and modifications of cassava starch. Carbohydrate Polymers. doi:10.1016/j.carbpol.2014.10.063 